\title{
A Study on Metaphors in Ti'i Ka Embu Nusi Discourse in Rongga Language
}

\author{
Yohanes Paulus Florianus Erfiani \\ English Study Program, Faculty of Educational Science, Universitas Timor \\ irnoerfiani21@gmail.com
}

How to cite (in APA Style): Erfiani, Y.P.F.(2018). A study methapors in Itii ka embu nusi discourse in Rongga language. Jurnal Pendidikan Bahasa dan Sastra, 18(1), 123-135, doi: 10.17509/bs_jpbsp.v18i1.12152.

Article History: Received (January 06, 2018); Revised (February 21, 2018); Accepted (March 22,2018).

Journal homepage: http://ejournal.upi.edu./index.php/BS_JPBSP

\begin{abstract}
This article is intended to investigate kinds of metaphors used in the discourse of Tï Ka Embu Nusi 'Giving Food to Ancestors' in Rongga Language (RL). It is also intended to investigate the cultural imagery expressed in the metaphors of Rongga language speakers (RLS). Many kinds of metaphors are used in the discourse of Tï Ka Embu Nusi in Rongga Language and Rongga Culture: structural metaphor, orientational metaphor and ontological metaphor. All metaphorical expressions belong to ontological metaphor. Nine of all the mataphors, beside belonging to ontological metaphor, are also belong to structural metaphor. Six of all the metaphors, beside belonging to ontological metaphor, also belong to orientational metaphor. It is also found the cultural imageryof the RLS was expressed in the metaphors appearing in the discourse of Ti'i Ka Embu Nusi. (1) RLS believe that the ancestors are still alive even though they are not caught in five senses of the human being. Their eyes still can see their children living in the world, their ears still can hear their prayers, their noses still can smell foods, their tongues still can taste sweet, salty, or bitter of the drinks and the food, and their skins still can touch the human being. (2) RLS believe that the ancestors have power to protect or even to curse their living generation. (3) RLS desire good life condition for living in the world. This can be obtained by doing Ti'i Ka Embu Nusi. (4) RLS desire long life in the world. This can also be reached by doing Tïi Ka Embu Nusi.
\end{abstract}

Keywords : Metaphor, Rongga Language (RL), Rongga Language Speakers (RLS), Ti’i Ka Embu Nusi Discourse.

\section{Kajian Metafora pada Wacana Ti'i Ka Embu Nusi dalam Bahasa Rongga}

\begin{abstract}
Abstrak: Penelitian ini berupaya untuk mengkaji jenis metafora yang digunakan dalam wacana Ti'i Ka Embu Nusi 'Memberikan Makanan kepada Leluhur' dalam Bahasa Rongga (RL). Artikel ini juga dimaksudkan untuk menyelidiki citra budaya yang diungkapkan dalam metafora Penutur Bahasa Rongga (RLS). Banyak jenis metafora yang digunakan dalam wacana Ti'i Ka Embu Nusi dalam Bahasa Rongga dan Budaya Rongga: metafora struktural, metafora orientasi dan metafora ontologis. Semua ekspresi metaforis merupakan bagian dari metafora ontologis. Sembilan dari semua matafora, selain milik metafora ontologis, juga milik metafora struktural. Enam dari semua metafora, selain milik metafora ontologis, juga milik metafora orientasi. Ditemukan juga citra budaya dari RLS yang diungkapkan dalam metafora yang muncul dalam wacana Tïi Ka Embu Nusi, yaitu (1) RLS percaya bahwa nenek moyang masih hidup meskipun mereka tidak tertangkap dalam lima indera manusia; (2) RLS percaya bahwa leluhur memiliki kekuatan untuk melindungi atau bahkan mengutuk generasi mereka yang masih hidup, dan; (3) RLS menginginkan kondisi kehidupan yang baik untuk hidup di dunia. Hal ini dapat diperoleh dengan melakukan Tïi Ka Embu Nusi. (4) RLS menginginkan umur panjang di dunia. Hal ini juga dapat dicapai dengan melakukan Tï Ka Embu Nusi.
\end{abstract}

Kata kunci: metafora, bahasa Rongga, Penutur Bahasa Rongga, wacana Ti’i Ka Embu Nusi. 


\section{INTRODUCTION}

In our daily life language is considered important because it has a great function as medium of communication among community members. It means that all human daily activities are made possible by means of language because it belongs to human being intimately tied up their life. Language has an important part of all human activities. The existence of language is needed by each person in the world. It means that language function as means of communication. By language, people can easily communicate, interact, and understand one another.

This article is of an interwoven study of both language and culture. Culture is a complex whole which includes knowledge, belief, art, morals, law, custom and any other capabilities and habits acquired by man as a member of society, Tylor (1958) in Michael (2011,p.121). And Language is a system of arbitrary vocal symbols used for human communication. This definition stresses that the basic building blocks of language are spoken words which combine sound with meanings. The symbols are arbitrary in the sense that the link between the sound and the meaning system varies from language to language. There is no necessary connection between the form of a word and its meaning (Wardhough in Maetrie, et al. 2000,p. 1).

All communities in the world need language. Therefore language plays and important role in the society. Each society has its own characteristic of language. Nida and Taber argue that each language has its own characteristic such as word order, word building capacity, sentence pattern, etc. It means that every language in the world has its own characteristics that might be different from any other language.

It cannot be argued that there were many researches in linguistic aspects that were already conducted by many researchers in this decade. Many researchers have started to research above language and they tried to identify micro and macro linguistic in one or many languages. It has generally known that micro linguistics consists of phonology, morphology, syntax and semantic and macro linguistic consists of psycholinguistics, sociolinguistics, anthropological linguistics, literature, cultural linguistics, etc. Micro linguistic aspects are really familiar in linguists ears because all aspects relate to the how to produce language (how to produce sentence) by human being. But the branch of macro linguistic is very extent and those aspects are difficult to identify and describe. Hence, this problem becomes the homework for the many linguistic researchers who intend to research in macro linguistic aspects.

By and large, the macro linguistic research does not only relate and discuss about language but it also relates to the culture. Language and culture cannot separate each others because there is language in culture and culture in language. They like two side of a coin. Therefore, it is very difficult to describe macro linguistic aspect of a language. In this era, people conducted a research to describe culture and language by using the theory sociolinguistic or anthropological linguistic theory, etc. There were many researches that used theory of sociolinguistic, anthropological linguistic, literature, etc. That is why the writer intends to conduct a linguistic research by using theory of Cultural Linguistic Perspective because this theory is rarely used by the other researchers.

This study is viewed from cultural linguistic perspectives (CLP). In line with this, a number of studies in the CLP were reviewed to see the chance of and inspire the study. Erom's Article (2011) investigated the system of lexicogrammar of Manggaraian Language. The lexicogrammar constitutes the cultural imagery of the MSC in seeing the past, the present, and the future time. Such lexicogrammatical system is based in the cultural imagery of the MSC. (1) To show the past time the lexicon one 'inside' is used, for example, one sua 'two days ago', one pitu 'seven days ago', etc. The past time is seen as something having been put inside, in 
the box, for example. Something put in the box cannot be moved. It means that the past cannot be changed. It is also shown by the lexiconolo in front of for the longer past time period, for example, one mingguolo 'last week', one wulangolo 'last month', one ntaungolo 'last year'. Something standing or put in front can be clearly seen. It means that the past is something clearly seen in the sense that it has been historically experienced, known, recognized. (2) To show the present time the lexicon ho'o'this' is used, for example, lesoho'o 'this day/today', minggoho'o 'this week', wulangho'o 'this month', ntaungho'o 'this year'. The present time is seen as something standing near to the speaker. Something near is clearly seen in the sense that it is still stepped on, experienced. (3) To show the future time the lexicon musi'behind/at the back' is used, for example, minggumusi 'next week', wulangmusi 'next month', ntaungmusi 'next year'. The future time is seen as something put behind. Something put behind cannot be seen. It means that the future cannot be seen in the sense that it cannot be predicted, or unknown. It delineates the belief of the MSC in terms controlling the future. They believe that no one knows what happens to everybody in the future. All those cultural linguistic studies inspired the decision of this topic. In this time, the writer wants to investigate another specific unique linguistic feature of ML.

Kövecses (1987: 53 - 55) investigated ontological metaphor. He proposed that in English the central metaphor for anger is ANGER IS THE HEAT OF A FLUID IN A CONTAINER (ontological metaphor). This metaphor gives rise to expressions such as the following:

\section{You make my blood boil.}

Simmer down!

I had reached the boiling point.

Let him stew.

The basic metaphor involves a scenario that describes what happens when anger becomes more intense: the fluid anger rises; anger produces steam and pressure on the container; when anger becomes too intense, the person explodes; when the person explodes, parts of her go up in the air and whatever was inside comes out.These scenarios give rise to expressions such as the following:

His pent-up anger welled up inside him.
(fluid rising)
She got all steamed up. (anger produces
steam)
He was bursting with anger. (anger
produces anger)
She blew up at me. (person explodes)
I blew my stack. (parts go up in air)
His anger finally came out. (what was
inside comes out)

Like any metaphor, there is a source domain and a target domain. The source domain is the conception of fluid in a container. The target domain is anger itself. A metaphor sets up a series of correspondences between entities from the two domains. Kövecses (1987,p.56 - 57) called these ontological correspondences. All those cultural linguistic studies inspired the decision of this topic.

To understand, direct, and limit the coverage of the study, a number of previous related basic concepts were defined. There are some important concepts dealing with this article that should be defined or conceptualized. This article talks about metaphorical expressions in the light of cultural linguistics perspectives. In line with this, in general, there are three important terms that should be conceptualized: discourse metaphor, and cultural linguistic perspectives.

Discourse scenarios consist of abstract imageryof speakers and listeners (Palmer, 1996,p.170). They are complex images of people speaking, listening and replying, or otherwise responding and reacting as they play roles in social scenes. It is because discourse scenarios are imagistic that we can either talk about them. Discourse scenarios reside within situation models, which are 
more inclusive representations of social context (Palmer, 1996,p.171). Situation model is defined as the organization and management of knowledge and metaknowledge and what a speaker knows and what a hearer knows (Schiffrin, 1987,p. 28). A situation model is relatively stable and therefore not quite the same as a participant's built-up, negotiated, model of an ongoing discourse situation in all its concrete remembered detail. Etymologically, the word Metaphor consists of two morphemes: meta 'above, beyond, behind' (Hornby, 1989,p.779) and phor or phora 'in composition' (Kirkpatrick, 1983,p. 962). Metaphor is the use of a word or phrase to indicate something different from (though related in some way to) the literal meaning as in "She has a beart of stone" (Hornby, 1989,p.780). A heart of human representing an attitude, will, or behavior, is in itself a metaphor altogether a metonymy. The heart which is a flash in substance here is compared with a stone that is hard. The heart or the strong will here is compared with a hard stone. Cultural linguistic perspective is a theory intended to approach human language. The theory of cultural linguistics (TCL) apparently intends to study human being through the language they speak and not merely to study the language they speak. What is studied in the human being is the ideology in his mind implied in the language he speaks which is called imagery by Palmer (1996,p.3). The linguistic analysis in the light of the TCL intends to uncover the imagery of the speaker, especially the native speaker that bases their language plays/expressions because language is the play of verbal symbols that are based in imagery. Imagery is originally shown in the dictionary of oxford English by Hornby (1989,p.619). Imagery is a mental representation of something (especially a visible object), not by direct perception, but by memory or imagination; a mental picture or impression; an idea, conception. Imagery is what we see in our mind's eye, but it is also the taste of a mango, the feel of walking in a tropical downpour, the music of Mississippi Masala. Our imaginations dwell on experiences obtained through all the sensory modes, and then we talk (Palmer, 1996,p. 3).

Cultural linguistic perspective is a theory intended to approach human language. The theory of cultural linguistics (TCL) apparently intends to study human being through the language they speak and not merely to study the language they speak. What is studied in the human being is the ideology in his mind implied in the language he speaks which is called imagery by Palmer (1996,p.3). Imagery or images are mental representation that begins as conceptual analogs of immediate perceptual experience from the peripheral sensory organs (1996,p.47). Sensory organs include eyes, ears, nose, tongue, and skin. In line with this, there exist imageries of visual, auditory, kinesthetic, olfactory, and temperature (Palmer, 1996,p.46). Here, the researcher will use TCL to identify the culture imagery of Rongga Speech Community (RSC) in using the metaphor. By and large, metaphor is a figurative speech concisely expressed by an implied analogy between two objects or idea, conveyed by the use of a word instead of another (Cunningham 1994,p.79). Rongga Speech Community is also used metaphor in another aspect of life of speakers as in ritual ceremonies and religions worship, for example; marriage negotiation, Kenduri, Ti'I ka embu discourse and etc.

The writer focuses here on the metaphors used in ritual ceremonies of Ti $i$ ka Embu Nusi. Ti,i ka Embu Nusi is a ritual ceremony of giving food to ancestors or souls of the dead. In that activity, the head of a clan usually express his words figuratively. Of course, it will be difficult to understand the real meaning of what he says because it is full of metaphorical expressions that have many hidden meanings.

Below are some words that are usually used by the head of a clan in Ti'i ka Embu Nusi ceremony.

Mori dedek palo ne'e kau bate mbeku rama kono one mbo ndia 
God endure with you all rubbish that enter at house this

'Oh God, avoid all sorts of diseases that will attack this family'.

In this expression the head of a clan tries to express his loyalty to God by using metaphors. The perspectives of cultural linguistic inspired the writer to design and conduct a study. The study was formulated in "A Title A Study On Metaphors In "Ti" Ka Embu Nusi" Discourse In RL. This topic is specified into two problems, (1) what are the kinds of metaphors used in "Ti' $\mathrm{Ka}$ Embu Nusi" Discourse?; (2) What is the cultural imagery that bases the metaphors used in "Ti'i Ka Embu Nusi" Discourse?

\section{METHOD}

This research is intended to investigate the kinds of metaphor used in the discourse of Ti'i Ka Embu Nusi of RL, the meaning, and the cultural imagery of the speakers of RL that bases the metaphor used. Deciding kinds of metaphor, its meaning, and the cultural imagery of the RLS is characterized by verbal description. So, this study belongs to qualitative study (Perry, 2005,p.75). Qualitative research works to uncover information from information-rich samples.

The data were gained from the informants. The informants are native speakers of RL living in East Manggarai regency. The data were in forms of oral. The oral data were obtained from oral answers of the informants to the written questionaires orally given to them. The data analysis is intended to uncover the meaning of linguistic expression. In this study, the data analysis is intended to uncover the culture imagery of the Rongga Speech Community (RSC) implied in the metaphor of Ti,i ka Embu Nusi discourse in RL.

The instruments used to obtain the data were in form of questionaires. The questionnaires are used to get the linguistic features of metaphorical meaning in RL. The questionnaires were constructed in Indonesian Language. The informants were asked to translate the questionnaires into RL.
The questionnaires having been translated into RL were written down and confirmed by having a close interview. Then all the answers were collected to be analyzed thereafter.

The practical steps applied in the analysis follow. (1) transcribing the discourse of Ti,i ka Embu Nusi discourse into Bahasa Indonesia. (2) translating the discourse of Ti'i ka Embu Nusi into English. (3) Selecting the metaphors existing in the discourse of Ti,i ka Embu Nusi (4) Listting the metaphorical expressions having been selected from the discourse of Ti'i ka Embu Nusi. (5) Translating all the metaphorical expressions having been listed into English. It is intended to know the equivalencyand the lexical meaning of the words constructing a metaphor existing in the discourse of Tïi ka Embu Nusi in English. (6) Translating the metaphorical expressions having been listed by idiomatic gloss into English. It is intended to see the real meaning of the metaphorical expreessions of RL existing in the discourse of Ti'i ka Embu Nusi in English. (7) Interpreting and describing the meaning of those metaphorical expressions. (8) Concluding the analysis to be the finding of this article.

\section{RESULTS AND DISCUSSION}

It contains the analysis of the metaphors used in Ti'T Ka Embu Nusi discourse in Rongga Language. The analysis is intended to uncover kinds of metaphor and cultural imagery of the Rongga speakers conveyed in the metaphors appearing in the discourse of Ti'I Ka Embu Nusi.

Kinds of Metaphor Used in Ti'i Ka Embu Nusi Discourse in Rongga Language and the Cultural Imageries

In general, the realization or carrying out the Ti'i Ka Embu Nusi discourse in the RLS is a culture practice of metaphor, especially ontological metaphor. It is so because the realization of this cultural practice is based on the metaphorical thinking and belief of the Rongga Language Speakers (RLS). It is a 
metaphorical thinking or belief because the dead fathers and dead mothers or dead parents and ancestors who are not caught by the five sensory organs or the five senses of the living human being. The dead parents and ancestors are thought or believed as living human being having the sensory organs or five senses: sight, olfactory, smell, taste, and touch. They are believed to have eyes to see, ears to hear, tongue to taste, nose to smell, and skin to touch. The five senses enrinch the mental imagery called cultural imagery by Palmer (1996). In this case, the characteristics of the human being are mapped or metaphorized to the dead parents and ancestors.

To do this the data in form of segments of the metaphorical expressions is presented followed with the comments. These comments are actually the anaylisis of the data. The analysis will show on what base certain metaphorical expression is classified into certain kind of metaphor: structural metaphor, orientational metaphor, or ontological metaphor. The detail information in the data follows.

[1] Zbiakauuramanu.

good you vein chick

'May you the vein of the cock be good'.

In this metaphorical expression, the RLS speaks to the rooster/cock, especially to its vein 'ura'. A rooster/cock is an animal. A rooster, especially its vein is believed to be able to listen to the prayer spoken by the RLS. Only human being can listen with full understanding to someone speaking. In this metaphorical expression, this kind of human characteristic is mapped or metaphorized to the rooster/cock. This metaphor belongs to ontological metaphor.

In this metaphorical expression, the RLS does hope that the vein of the rooster is good in shape. Good condition of the vein metaphorizes good condition of life of the human being, the RLS. Good life condition is actually the life orientation of the RLS. Good life condition as a normal life orientation of human being in this metaphor is expressed in the phrase Zhiakauuramanu 'The vein of the chick should be good'. Good life condition is metaphorized with or mapped to good condition of the vein of the cock'shiauramanu'. Good life condition is really hoped to be delineted in the vein ' $u r a$ ' of a rooster/cock. This is an orientational metaphor, beside an ontological metaphor.

The vein of the cock 'uramanu' is used to be the food for the dead parents and ancestors. The dead parents and ancestors are believed to live like human being. As a living human being, they must feel hungry. Feeling hungry can only be overcome by having meals. So, they are given food 'ti' ika'. Giving them food is done in the traditional ritual called Ti'I Ka Embu Nusi. The Ti'I Ka Embu Nusi is a traditional discourse culturally practiced by the RLS which is full of metaphorical expressions. So, this metaphorical expression also belongs to ontological metaphor.

The cultural practice Ti'I Ka Embu Nusi of the RLS asking good life condition to the dead parents and ancestors also implies that good life condition can be obtained by giving food consisting of the vein, heart, and crop of the cock or rooster with rice, salt, water, and tuak 'traditional alcoholic drink' to the dead parents and the ancestors. The dead parents and the ancestors are believed to have power to fulfil good life condition desired by the RLS. This belief is a kind of ontological metaphor.

This cultural practice of metaphorical expression is important for the RLS. It is important because it is based in the cultural imagery of the RLS. The vein of the rooster/cock is important in cultural imagery of the RLS. The good life condition is also important in the cultural imagery of RLS. So, the practice of this metaphor in the life of the RLS is based in the cultural imagery of the RLS.

[2] Ndia kami ramba tauti'ika, meninene'eemalawaembunusi. 


\section{this we want to give food you mother and father include ancestor 'We want to give ritual offerings to you father, mother, and ancestors'. \\ [3] Meuembunusi, dhengine'e kami one meuineemalawaembunusi. \\ you ancestor, ask by us to \\ you mother father and ancestor \\ 'We ask you father, mother, and ancestor'.}

In these metaphorical expressions the RLS speaks to the dead father 'ema', mother 'ine' and ancestors 'embunusic. The RLS speaks in terms of giving food and asking something. They are given food because they are believed to feel hungry and to have meals to live. Feeling hungry and having meals is one of the characteristics of human being. They are given food because they are culturally believed to be still alive like living human being. Feeling hungry can be overcome by having meals or eating something.

The dead parents and the ancestors are also asked something because they are believed to have ears to listen to the prayers asked by the RLS. The dead parents and the ancestors are also asked something because they are believed to have power to do and to give something good or bad to their children living in the world, including good life condition as has been mentioned above. Something good or bad happening to the human being, the RLS, can be caused by the dead parents and the ancestors. To be believed to feel hungry, to listen to the prayer, and to do something good or bad to the human being is a kind of metaphorical belief. So, this metaphors are ontological metaphors.

The practice of this metaphor of the RLS is important. It is so because it is based in the cultural imagery of the RLS. In other words, this metaphor expresses the cultural imagery of the RLS. It means that in the cultural imagery of the RLS, the dead parents and ancestors are not dead but are still alive, even though they are not caught in the five senses. Not only are they still alive, but also have power to protect, to bless, and even to curse the human being. For they are belived to be still alive like living human being they need food. Giving food to the dead parents and ancestors is a kind of worship of the human being, their children, to them. For they are belived to be still alive like living human being they are able to listen to the prayer. For they have power the RLS ask something to them for the importance of life in the world.

[4]

$$
\begin{aligned}
& \text { Ai kombe ndia kami neki weki ą̧hi } \\
& \text { ka'e lawa ana tau nunu } \\
& \text { because night this we collect body } \\
& \text { sister brother and child to tell } \\
& \text { 'Tonight we, brothers, sisters, and } \\
& \text { relatives are sitting together to pray } \\
& \text { to you'. }
\end{aligned}
$$

In this metaphorical expression, the RLS say the prayer to their dead parents and ancestors. The dead parents and ancestors are believed to have ears to listen to the prayer of the children living in the world. The ability to hear the voices of the human being is mapped or metaphorized to be the ability of the dead parents and ancestors. This metaphor belongs to ontological metaphor.

In this metaphor, human being having ears are mapped to be the ears of the dead parents and the ancestors having ears to hear the prayer of their children in the world. Besides, the structure of human body nekiweki 'body collect' is mapped to the structure of other concept: the unity among people. Here the phrase nekiweki 'body collect' is metaphorically thought a symbol of unity among human being. This metaphor also belongs to structural metaphor.

The whole part of the body 'weki' metaphorizes the unity a community. The word body 'weki' consists of unity of many parts of the body: head, hands, and legs, in general. The community of human being consists of many persons with their various differences: gentital status, social status, economic status, etc. So, it is no doubt that 
this metaphor belongs to structural metaphor.

The practice of this metaphorical expression is important. It is so because it is based in the cultural imagery of the RLS. The appearance of this metaphor in RL is based in the cultural imagery of the RLS. In other words, this metaphor expresses the cultural imagery of the RLS. It means that the unity among people and the structure of human body are important in the cultural imagery of RLS.

[5] Ti'i ka ne'e baghi wae men ina anak kami Teli tau nunumeu. give food and give drink you cause child our Teli want talk you 'We give you ritual offering because our child, Tely, wants to say'.

[6] Kaحbitako'a seminar, ndiarambalanjutskripsi. She finish seminar, this want continue skripsi

'She has finished seminar, now she wants to continue to write a thesis'.

[7] Ramba one wekiana kami lawaanane'eembumeu. so in body child our as child and grandchild you

'May the body of our child, your child and altogether your grandchild'.

[8] Kami dhengi ramba one weki ana kami ne'e men bholo tau jaga.

we ask in self child our just
you only who keep

'We ask you to look after our child'.

[9] Tau kopomoloramba one weki maene'erara. for put in stable good so in self don't feel hot

fatama'e papa azhemae pale wood don't block, rope don't block

'Protect our child to be free from illness and avoided from hindrance'.

In these metaphors, the RLS speak to the dead parents and the ancestors. The RLS tell them about the aim of offering drinks and foods. The RLS also ask them to bless in doing something, in writing thesis, to look after and to protect their body and soul from illness. The dead parents and ancestors are believed to have ears to hear the prayer, a mouth to drink and to eat, an ability and power to protect the bodies and souls of the human being. This belief is linguisticaly expressed in the metaphors. So these metaphorical expressions belong to ontological metaphor.

In these metaphors the mouth to eat or to speak, the ears to listen, the body to do any ability and the power of human being are mapped or metaphorized to those of the dead parents and ancestors. In this case the structure of human body is mapped to the structure of the body of the dead parents and ancestors. These metaphors also belong to structural metaphors.

The practice of these metaphorical expressions is important. It is so because it is based in the cultural imagery of the RLS. The appearance of this metaphor in RL is also based in the cultural imagery of the RLS. In other words, these metaphors express the cultural imagery of the RLS. It means that in the cultural imagery of the RLS, the dead parents and ancestors are not dead but are still alive, even though they are not caught in the five senses. They are also believed to have power to protect and to bless their children, the RLS.
[10] Ange manga mbana ko tana, ndaughililazhamezhe.
maybe be hot ground, under there road

'There may be dangers down there in the streets'.

In this metaphorical expression, the RLS speak to their dead parents and ancestors. They ask them whether there is a danger in the street that might endanger the human being. The dead parents and ancestors are believed to have ears to listen to the human being, RLS ask. They are also believed to have imagery to understand what is being 
asked and mouth to speak or to answer. The ability to hear and understand the voices of the human being and to speak or answer is mapped or metaphorized to be the ability of the dead parents and ancestors. This belief is linguisticaly expressed in the metaphor. This metaphor belongs to ontological metaphor.

In this metaphor, the structure of climate or weather mbanakotana 'hot land' is mapped to the structure of other concept: the dangers or illness suffered by human being. Here the phrase mbanakotana 'hot land' is metaphorically thought or considered as illness usually suffered by human being. The characteristic of the hot weather is equalized with the characteristic of the temperature of human body. Hot land is not good for living things: human beings, plants, and animals. Hot temperature for human body is not good for human being for it indicates bad condition or illness. This belong to structural metaphor.

The practice of this metaphorical expression is important. It is so because it is based in the cultural imagery of the RLS. The appearance of this metaphor in RL is also based in the cultural imagery of the RLS. In other words, this metaphor expresses the cultural imagery of the RLS. It means that the structure of the climate or weather mbanakotana 'hot land' and good health are important in the cultural imagery of the RLS.

[11] Dhengine'e kami ana kami pakakakomomanulalu

hope from us, child our must crow like rooster

'We do hope that our child crows like a rooster',

Iemojaran gazha, ramba kazhi maemo wako ana balo

neigh like horse race, so

she isn't as life orphan

'neighs like a racing horse, so his/her life is not like an orphan'.
[12] Mae mokerirawnwewu, landi tau bhohoko lo, mosako

not like coarse grass not root, but make strong body, healthy

'Not like coarse grass that does not have roots but make us physically strong',

landi kali mobhetonggilileko, nanggilinua
but also like bamboo in middle
valley, rattan around village
'like bamboos in the valley, rattan
around the village'.

In these metaphorical expressions, the RLS speak to their dead parents and ancestors. They ask their dead parents and ancestors to make them to crow like a rooster, to neigh like a horse, to grow like bamboo and rattan. The dead parents and ancestors are believed to have ears to listen to the RLS asking something. The dead parents and ancestors are also believed to have an ability to understand what is asked. The ability to hear and to understand something spoken is mapped to be the ability of the dead parents and ancestors. This is an ontological metaphor.

In this metaphor, the human being, the RLS really want to have the characteristics of animals: a rooster 'manu' and a racing horse 'jarangazha' and the characteristics of plants: bamboo and rattan. The RLS really want to be able to crow like a cock/rooster'manulalu', to neigh like a racing horse'jarangazh $h$ ', to have strong root and big colony like bamboo and rattan. Only manulalu 'cock/rooster' that crows, only jara 'horse' that neighs, and only a plant, bhetonggilileko 'like a bamboo in the valley', and uanggilinua 'rattan around the village' that have strong roots and big colony. The phrases of kakomomanulalu 'the crows like a rooster', iemojarangazha 'neighs like a racing horse', landi kali mobhetonggilileko 'but like a bamboo in the vallery', and uanggilinua 'like rattan around the village' are mapped to the human being. The characteristics of domestic animals: manulalu 'cock' and jarangazha 'racing horse', and plants: bamboo and rattan are equalized with 
the characteristic of the human being, the RLS. In this metaphor the human being can crow like a rooster, can neigh like a horse, and have strong root and big colony like bamboo and rattan. Undoubtedly, this is an ontological metaphor.

Crowing like a rooster and neighing like a horse have at least two metaphorical meanings. First, it delineates good health of the RLS. The common knowledge says that only healthy rooster that can crow and only healthy horse that can neigh. Second, it delineates the high intelligence of the human being. One indicator of having high inelligence of human being is that he can speak. Speaking here is metaphorized with the crowing and neighing. It is understandable because the discourse of Ti'iKaEmbuNusi was done aiming at being successful in writing and defending the thesis at the thesis examination to end the study in a university: WidyaMandira Catholic University, Kupang.

Bambo and rattan grow in a colony. So it is very difficult to be felled by the typhoon. Growing in a big colony of the bamboo and rattan is metaphorized to the human being, the RLS to have many members of the family and healthy.

The presence of this metaphor in RLS is important. It is so because it is also based in the cultural imagery of the RLS. In other words, this metaphor expresses the cultural imagery of the RLS. It means that the domestic animals: manulalu 'rooster/cock' and jara 'horse' and the plants: bamboo and rattan are important in the cultural imagery of the RLS. In fatct, traditionally, the bamboo can be used to be the balk of the house, and rattan can be used for the raw material of many things: baskets, shield used in caci dance or war/duel, sticks for the olds.

$$
\begin{aligned}
& \text { Kami kali batheazhikaelawaanaembuwoso } \\
& \text { we also all sister brother with } \\
& \text { child grand many }
\end{aligned}
$$

'We together with brothers, sisters, and relaticves say'.

[14] Mae bhekaghea, landi tau po'omokondi'ilundu don't broke separate, but make sit like as sit tent 'Don't break us into pieces, but make us unity'.

[15] mokajuiju, rambalundumaendhoho,
anamaeghole
and wood tied, so that tent not
oblique, child don't fall

'Make us unity to be strong so we will not fall'.

In these metaphorical expressions, the RLS speak to their dead parents and ancestors. They speak about the presence of the families and relatives when saying the prayer. They also pray to not put them into pieces, except peace and unity to make them happy and strong. They also ask to sit together on a tent. Tent is usually high so sitting together on it can see many things and can be seen by many people around. Sitting on a tent metaphorizes the good life condition, peace, and happiness of the families and relatives. The desire to live in unity, good condition, peace, and happiness is life orientation of the RLS. So it is no doubt that these belong to orientational metaphors.

In these metaphors, the human being, the RLS say the requests to the dead parents and the ancestors. The dead parents and the ancestors are culturally believed to have ears to listen to the prayer of the RLS. They are also culturally believed to have power to put human being in life condition of unity, peace, strong, and happiness. This belief is a kind of ontological metaphor, beside orientational metaphor.

The presence of these metaphors in RLS is important. It is so because it is also based in the cultural imagery of the RLS. In other words, these metaphors express the cultural imagery of the RLS. It means that in the cultural imagery of the RLS, the dead parents and ancestors are not dead but are still alive, even though they are not caught in the five senses. For they are believed to be still alive like living human being they are able to listen to the human being saying their prayers. They are believed to have power to 
give peacefull life and strong and healthy physic to human being. They are believed to be the source of peaceafull life and strong and healthy physic.

\section{[16] Ana kami kodhefaipakaumulewasaizhelesedhum bisa \\ child our girl can old long until become like grandmother}

'May our daughter have long life like our grandmother'.

[17] Ana kami kodhehaki pakaumu lewasaizhe lendo angembo

child our boy must old long until become like grandfather

'May our son have long life like our grandfather'.

In these metaphorical expressions, the RLS speak to their dead parents and ancestors. They ask to be given a long life living in the world. The model of long life is their grandparents. The dead parents and the ancestors are culturally believed to have ears to listen to the prayer of the RLS. They are also culturally believed to have power to give human being a long life. This belief is linguistically expressed in a metaphor. These belong to ontological metaphors.

The RLS ask the prayer to be given a long life living in the world like their grandfather and grandmother. The model of long life is their grandparents. The long age is identic with the age of the grandparents. The long age is equalized with the age of the grandparents. The long age is metaphorized or mapped, or compared with the age of the grandparents. These metaphors belong to the structural metaphors, beside ontological metapors.

It is clearly seen in these metaphors that long age is the life orientation of the RLS. The model of this orientation is the grandparents. It is understandable because they are thought to have long age. The grandparents are considered as the human generation that have long age. In fact they bear sons and daughters who also bear other sons and daughters. They can witness the birth and the growth of their sons and daughters and grandsons and granddaughters. These metaphors also belong to orientational metaphors, beside structural and ontological metaphors.

These metaphors in RLS are important. They are important because they are also based in the cultural imagery of the RLS. In other words, these metaphors express the cultural imagery of the RLS. It means that in the cultural imagery of the RLS, the dead parents and ancestors are not dead but are still alive, even though they are not caught in the five senses. For they are believed to be still alive like living human being they are able to listen to the human being saying their prayers. They are believed to have power to give long age to the human being. They are believed to be the source of having long age living in the world. Another cultural imagery of RLS conveyed in the metaphors is that they desire a long age like their grandparents.

\section{[18] Ndau tara Kami nunu meninene'eema embu nusi, \\ that because we talk you mother and father ancestors \\ 'That is why we would tell you grandfather and grandmother and ancestors'.}

[19] Ndiamanupakauraz̧biapu'uz̧etaulusaiwa'i this cock may vein good from on head until foot

'May the vein of this cock be good from head to feet'.

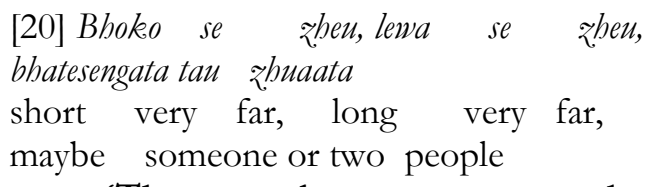

'There may be one or two people who are near or far',

[21] ngedho kodhi pangga bhoko, rasa mala kazi.

look jealous very hate, avoided, amen, return to them

'who are jealous and hate us keep them away and give it back to themselves, amen'. 
In these metaphors, the human being, the RLS say the requests to the dead parents and the ancestors. The dead parents and the ancestors are culturally believed to have the characteristics of the living human being. They are addressed the prayer because they are culturally believed to be still alive like living human being. They are believed to be able to listen to the human being saying their prayer and answering them. The RLS ask the prayers to be given a peacefull life. They also pray for avoidance or being protected from any kinds of life difficulties caused by other people. The peacefull life is shown by the vein of the cock or rooster. These metaphors belong to ontological metaphors.

These metaphors in RLS are important. They are important because they are also based in the cultural imagery of the RLS. In other words, these metaphors expresse the cultural imagery of the RLS. It means that in the cultural imagery of the RLS, the dead parents and ancestors are not dead but are still alive, even though they are not caught in the five senses. For they are believed to be still alive like living human being they are able to listen to the human being saying their prayers. They are believed to have power to give peacefull life and avoidance from any kinds of life difficulties.

\section{Cultural Imagery of the RLS Expressed in the Metaphor}

Cultural imagery is what we see in our mind's eye (Palmer, 1996: 3). Cultural imagery is what the RLS see in their mind's eye that bases the metaphors used in the cultural discourse of Ti'iKaEmbuNusi 'Giving Foods to Ancestors' culturally practiced by the RLS, on the one hand. On the other hand, the metaphors used in the cultural discourse of Ti'I Ka Embu Nusi express or bear some cultural imagery of the RLS. Cultural imagery bases all the cultural practice of the RLS actualized in RL, in the play of metaphors appearing in the cultural discourse of Ti'T Ka Embu Nusi. Cultural imagery bases the ideology of the RLS.
The cultural imageries have been actually found in the data analysis. Those cultural imageries are only summarized here in a general idea. Considering the literal and metaphorical meaning of the metaphors having been presented in the previous subchapter, it shows very clear the cultural imageries of the RLS, as follow, (1) RLS believe that the ancestors are still alive like living human being. Like living human being, they have five senses that are still working. Their eyes still can watch life of the human being, their ears still can listen to the prayers, their noses still can smell the foods and drinks, their tongues still can taste foods and drinks, and their skins still can touch the human being; (2) RLS believe that the ancestors have power to protect or even to curse the human being, their children; (3) Like other ethnics, RLS desire good life condition when living in the world. This can be reached by giving ancestors food consisting of the vein, heart and crop of the cock or rooster, rice, salt, water, and tuak 'traditional alcoholic drink', and; (4) Like any other people, RLS desire long life in the world. This can be reached by giving ancestors food consisting of the vein, heart, and crop of the cock or rooster, rice, salt, water, and tuak 'traditional alcoholic drink'.

\section{CONCLUSION}

The twenty chunks of the metaphors appearing in the discourse of Ti'i Ka Embu Nusi involve into three kinds of metaphors: structural metaphor, orientational metaphor, and ontological metaphor. However, the ontological metaphor is presented first and the two others. All the twenty chunks of the metaphorical expressions recorded in the data belong to ontological metaphors. It is so because in all the segments of metaphorical expressions the characteristics of living human being are mapped or metaphorized to the dead parents or ancestors. All the segments of the metaphorical expressions are addressed to the ancestors although they have died. They have died but they are believed to be still alive by the RLS. This kind belief is 
metaphorical. The ancestors are metaphorically believed to be still alive, to have the still working five senses, to have power to protect or to curse their still living children/generation in the world. The metaphors expressing this belief belong to ontological metaphors. Nine from the twenty chunks of the metaphorical expressions also belong to the structural metaphor, beside ontological metaphor. Those metaphorical expressions include numbers [4] - [10], [16] - [17]. In these metaphors the mouth to eat or to speak, the ears to listen, the body to do any ability and the power of human being are mapped or metaphorized to those of the dead parents and ancestors. In this case the structure of human body is mapped to the structure of the body of the dead parents and ancestors. The structure of human bodyneki weki 'body collect' is mapped to the structure of other concept: the unity among people.The structure of climate or weather mbana ko tana 'hot land' is mapped to the structure of other concept: the illness suffered by human being [10]. The structure of long age is equalized, metaphorized, mapped, or compared with the age of the grandparents [16] and [17]. These metaphors belong to structural metaphors. Six of the twenty segments of the metaphorical expressions also belong to orientational metaphors. They include the metaphors numbers [1], [13] - [17]. Good life condition is metaphorized with or mapped to good condition of the vein of the chick's bia ura manu' [1]. The desire to live in unity, good condition, peace, and happiness is life orientation of the RLS [13] [15].Long age is the life orientation of the RLS. The model of long life orientation is the grandparents [16] - [17].

Cultural imagery is what the RLS see in their mind's eye that bases the metaphors used in the cultural discourse of Ti'i $\mathrm{Ka}$
Embu Nusi 'Giving Foods to Ancestors' culturally practiced by the RLS. The metaphors used in the cultural discourse of Ti'i Ka Embu Nusi express or bear some cultural imagery of the RLS. Cultural imagery bases all the cultural practice of the RLS actualized in RL, in the play of metaphors appearing in the cultural discourse of Tï Ka Embu Nusi. Cultural imagery bases the ideology of the RLS.

\section{REFERENCES}

Erom, K. (2011). How to see the past, the present, and the future of manggaraian people: culture linguistic perspective.Reference: Journal of Language and Language Teaching. Vol. 1 (4),151-161.

Hornby. A. S. (1989). Oxford Advanced Learner's Dictionary. Oxford: Oxford University Press.

Kirkpatrick, E. M. (1983). Chambers 20 th Century Dictionary. Great Britain: W \& R Chambers Ltd.

Kövecses, Z. (1987). Metaphors of Angers: Pride and Love. Philadelphia: John Benjamins.

Maetrie, et al. (2000). No necessary connection between law and morality philosophy essay. Retrieved from: https://www.ukessays.com/.../nonecessary-connection-between-lawand-morality-phil.

Michael, A. (2011). Human culture: what is culture? $\quad$ Retrieved from: https://www2.palomar.edu/anthro/ culture/culture_1.htm.

Palmer, G. B. (1996). Toward a Theory of Cultural Linguistics. USA: University of Texas Press.

Perry, Jr. F.L. (2005). Research in Applied Linguistics: Becoming a Discerning Consumer. New Jersey: Lawrence Erlbaum Associates Publishers. 